\title{
Responses of an oyster host (Crassostrea virginica) and its protozoan parasite (Perkinsus marinus) to increasing air temperature
}

\author{
Jennafer C Malek ${ }^{\text {Corresp., }}{ }^{1}$, James E Byers ${ }^{1}$ \\ ${ }^{1}$ Odum School of Ecology, University of Georgia, Athens, GA, United States \\ Corresponding Author: Jennafer C Malek \\ Email address: malekjc1@gmail.com
}

\section{Background.}

Changes in climate are predicted to influence parasite and pathogen infection patterns in terrestrial and marine environments. Increases in temperature in particular may greatly alter biological processes, such as host-parasite interactions. For example, parasites could differentially benefit from increased reproduction and transmission or hosts could benefit from elevated immune responses that may mediate or even eliminate infections. In the southeastern United States, the Eastern oyster, Crassostrea virginica, is infected by the lethal protozoan parasite, Perkinsus marinus. Under field conditions, intertidal (airexposed) oysters have been found to have significantly higher $P$. marinus infection intensity and marginally higher infection prevalence than subtidal (submerged) oysters. During summer, air temperatures are much warmer than water and this exposure of intertidal oysters to higher temperatures is a suggested mechanism for increased infection intensity.

\section{Methods.}

We simulated intertidal exposure using controlled laboratory experiments to determine how host traits (survival and immune response) and parasite infection intensity will respond to elevated air temperature ranging from $27^{\circ} \mathrm{C}$ to $53^{\circ} \mathrm{C}$ during emersion at low tide. In Georgia, where our work was conducted, the average summer water temperature is $29^{\circ} \mathrm{C}$ and the average maximum high air temperature in July is $33^{\circ} \mathrm{C}$ (though oysters have been shown to survive at much higher air temperatures).

\section{Results.}

Host survival declined as temperature increased, with a definitive drop-off between $39-43^{\circ} \mathrm{C}$. Negative effects of air temperature on host immune response (phagocytic activity) were detectable only at extremely high temperatures $\left(47-50^{\circ} \mathrm{C}\right)$ when hosts were suffering acute mortality. Parasite infection intensity peaked at $35^{\circ} \mathrm{C}$.

\section{Discussion.}

Our results suggest that an increase in average summer air temperature to $35^{\circ} \mathrm{C}$ or higher could affect oyster survival directly through temperature-related impacts in the short-term and indirectly through increased $P$. marinus infection intensity over the long-term. 
1 Responses of an oyster host (Crassostrea virginica) and its protozoan parasite (Perkinsus

2 marinus) to increasing air temperature

3

4 Jennafer C Malek ${ }^{1}$, James E Byers ${ }^{1}$

5

6 1. Odum School of Ecology, University of Georgia, Athens, GA 30602

7 Corresponding author: Jennafer C Malek ${ }^{1}$

8 Email address: malekjc1@gmail.com

9

10

11

12 


\section{Abstract}

\section{Background.}

15 Changes in climate are predicted to influence parasite and pathogen infection patterns in

16 terrestrial and marine environments. Increases in temperature in particular may greatly alter

17 biological processes, such as host-parasite interactions. For example, parasites could

18 differentially benefit from increased reproduction and transmission or hosts could benefit from

19 elevated immune responses that may mediate or even eliminate infections. In the southeastern

20 United States, the Eastern oyster, Crassostrea virginica, is infected by the lethal protozoan

21 parasite, Perkinsus marinus. Under field conditions, intertidal (air-exposed) oysters have been

22 found to have significantly higher $P$. marinus infection intensity and marginally higher infection

23 prevalence than subtidal (submerged) oysters. During summer, air temperatures are much

24 warmer than water and this exposure of intertidal oysters to higher temperatures is a suggested

25 mechanism for increased infection intensity.

26 Methods.

27 We simulated intertidal exposure using controlled laboratory experiments to determine how host

28 traits (survival and immune response) and parasite infection intensity will respond to elevated air

29 temperature ranging from $27^{\circ} \mathrm{C}$ to $53^{\circ} \mathrm{C}$ during emersion at low tide. In Georgia, where our work

30 was conducted, the average summer water temperature is $29^{\circ} \mathrm{C}$ and the average maximum high

31 air temperature in July is $33^{\circ} \mathrm{C}$ (though oysters have been shown to survive at much higher air

32 temperatures).

\section{Results.}

34 Host survival declined as temperature increased, with a definitive drop-off between $39-43^{\circ} \mathrm{C}$.

35 Negative effects of air temperature on host immune response (phagocytic activity) were 
36 detectable only at extremely high temperatures $\left(47-50^{\circ} \mathrm{C}\right)$ when hosts were suffering acute

37 mortality. Parasite infection intensity peaked at $35^{\circ} \mathrm{C}$.

38 Discussion.

39 Our results suggest that an increase in average summer air temperature to $35^{\circ} \mathrm{C}$ or higher could

40 affect oyster survival directly through temperature-related impacts in the short-term and

41 indirectly through increased $P$. marinus infection intensity over the long-term.

42

43 


\section{Introduction}

45 Anthropogenically driven changes in climate are influencing terrestrial and marine ecosystems,

46 from individual species to entire communities (Janzen, 1994; Crick \& Sparks ,1999; Walther et

47 al., 2002; Mortiz et al., 2008). Air and water temperature, seawater acidification, and sea level

48 are some of the environmental factors projected to increase due to climate change (IPCC, 2014a).

49 Climate models predict that global mean surface air temperature will increase anywhere from

$50 \quad 0.3^{\circ} \mathrm{C}$ to upwards of $4.5^{\circ} \mathrm{C}$ by 2090 , with more extreme region-specific increases expected

51 (IPCC, 2014a, b). Such changes in temperature will likely drive considerable variation in

52 biological processes such as metabolic rate (Gillooly et al., 2001; Ganser, Newton \& Haro, 2015)

53 and immune function. For example, temperature can alter both innate and adaptive immune

54 functions including phagocytic and phenoloxidase activity (Cheng et al., 2004; Wang et al.,

55 2008) and the expression of acquired immune genes (Raffel et al., 2006; Dittmar et al., 2014).

56 Stimulation or suppression of these important biological processes caused by changes in

57 temperature can affect organismal responses to other factors.

59 One of the primary uncertainties about the expected shifts in temperature is how such changes

60 might alter interspecific interactions, such as host-parasite interactions. If parasites respond more

61 favorably to increases in temperature than their hosts, through higher parasite growth and

62 reproduction, a warmer world may be a sicker world (Harvell et al., 2002; Harvell et al., 2004;

63 Lafferty, Porter \& Ford, 2004). Some parasites have already demonstrated positive responses to

64 climate-induced increases in temperature, including increased geographic ranges (Pounds et al.,

65 2006; Ford \& Smolowitz, 2007) and increased transmission between hosts (Mouritsen \& Jensen,

66 1997; Moore et al., 2000; Poulin, 2006). In the Caribbean, for instance, increases in both the 
67 prevalence (proportion of infected individuals in a population) and growth rate of yellow band

68 disease lesions in corals co-varied significantly with increases in annual mean water temperature

69 from 1999 to 2007 (Harvell et al., 2009). Such positive parasite responses to increasing

70 temperature may be connected to temperature-induced changes in host characteristics, including

71 increased physiological stress (Lesser \& Farrell, 2004; Allen et al., 2008), suppressed immune

72 responses (Chisholm \& Smith, 199; Cheng et al., 2009; Al-Zahraa, 2008), or overstimulated and

73 harmful immune responses (Wang et al., 2012).

75 Alternatively, increasing temperature may benefit hosts more than parasites if the host responds more favorably physiologically than its parasites (Gehman, Hall \& Byers, 2018). For example, coral and gorgonian hosts have demonstrated stimulated immune responses when exposed to increasing temperature (Ward, Kim \& Harvell, 2007; Mydlarz et al., 2008; Mydlarz et al, 2009).

Cheng et al. (2004) observed that Taiwan abalone had significantly higher respiratory burst activity (rapid release of reactive oxygen species) when exposed to higher $\left(32^{\circ} \mathrm{C}\right)$ compared to control $\left(28^{\circ} \mathrm{C}\right)$ water temperatures. Mydlarz et al. (2009) found that the coral Montastraea

82 faveolata had higher prophenoloxidase activity (an important precursor to other immune responses used in parasite resistance) when exposed to higher than normal water temperature.

Increasing temperature can also stimulate amoebocyte production, and subsequently melanosome production, in sea fans which concurrently help fight fungal parasite infection (Mydlarz et al., 2008). Though a range of host immune responses have been found to be stimulated by increasing temperature, the larger implications of these effects are still uncertain. Because effects of increasing temperature on host immune response, and thus host-parasite interactions, can be varied and are often based on observational studies, we sought to experimentally examine how 
90 both host physiological traits and corresponding parasite infection intensity will be influenced by

91 increasing temperature.

92

93 Along the East and Gulf of Mexico coasts of the US, the eastern oyster, Crassostrea virginica, is 94 an ecologically and economically important ecosystem engineer that creates complex reef habitat 95 and supports a commercial fishery (Bahr and Lanier 1981, Byers et al. 2015). Throughout most

96 of its range, C. virginica is infected by the protistan parasite Perkinsus marinus, which can cause

97 considerable host mortality. First discovered in the Gulf of Mexico in the 1950s (Mackin, Own

98 \& Collier, 1950), P. marinus has expanded its range from the mid-Atlantic to the Northeast in

99 the last several decades, primarily due to climate-driven increases in winter water temperatures

100 (Ford \& Chintala, 2006; Ford \& Smolowitz, 2007). Environmental drivers of P. marinus

101 infection patterns are numerous, including water temperature, salinity, diel-cycling hypoxia, tidal

102 elevation, and weather events such as El Niño/Southern Oscillation (ENSO) and the North

103 Atlantic Oscillation (NAO) (Ford \& Tripp, 1996; Soniat et al, 2006; Soniat et al., 2009;

104 Breitburg et al., 2015; Keppel et al., 2015, Malek \& Byers, 2017). Additionally, the activity and

105 function of oyster hemocytes, which are the primary line of oyster immune defense, are also

106 affected by water temperature, salinity, and diel-cycling hypoxia (Hégaret, Wikfors \& Soudant,

107 2003; Keppel 2014). Thus, characteristics of both host and parasite in this system are affected by

108 factors that are predicted to be altered by climate change.

109

110 Many of the environmental drivers of both P. marinus infection patterns and C. virginica

111 immune response are related to temperature. Malek \& Byers (2017) observed that intertidal

112 oysters had significantly higher intensity (abundance of infection within an individual) and 
113 tended to have higher prevalence of $P$. marinus infections than subtidal oysters. They suggested

114 that the mechanism driving this pattern could be exposure to higher mean temperatures or higher

115 variability of conditions, including air temperature, during periods of emersion. In this study, we

116 further investigated the role of air temperature in the $C$. virginica - P. marinus system.

117 Specifically, we evaluated if increasing air temperature, including temperatures that are likely to

118 occur with climate change, affect $C$. virginica survival and immune response, as well as $P$.

119 marinus infection intensity.

120

121 Materials and methods

122 Oyster Collection, Preparation, and Maintenance

123 To achieve a more comprehensive understanding of the effects of increasing air temperature on

124 host survival and immune response, we measured these variables in both the presence and

125 absence of $P$. marinus infection. In early May 2014 we analyzed the intertidal oyster population

126 at Priest Landing, Savannah, Georgia, USA (31 $57^{\prime} 44.2^{\prime}$ N, $\left.81^{\circ} 00^{\prime} 46.0^{\prime \prime} \mathrm{W}\right)$ for $P$. marinus

127 prevalence. Using a destructive quantitative PCR assessment (qPCR, see Parasite Assessment

128 below) we measured a baseline prevalence of $60 \%(n=28)$. Using this prevalence, we assumed

129 that oysters collected from this population would provide roughly equal numbers of infected and

130 uninfected hosts (we were unable to determine infection status of individuals until the conclusion

131 of experiment due to the destructive nature of parasite assessment). We randomly collected 225

132 individual oysters (30-100 mm shell height) from intertidal reefs in late May and cleaned them of

133 sediment and fouling organisms such as juvenile oysters. In the lab we tagged individuals with

134 unique bee tags (The Bee Works), recorded shell heights, and allowed $72 \mathrm{~h}$ of acclimation to

135 water conditions of $27^{\circ} \mathrm{C}$ prior to beginning air temperature treatments. 
137 To prevent P. marinus transmission during the experiment, we held oysters individually in

138 independent $946 \mathrm{ml}$ containers with labels that corresponded to oyster ID tags. We filled

139 containers with artificial seawater (salinity $\sim 25 \mathrm{psu}$, Instant Ocean dissolved in tap water) and

140 changed the water every 2-3 d to limit accumulation of feces and nutrients. Each container had

141 its own air supply run through a hole in the container lid, with average dissolved oxygen

142 concentrations ranging from $2.9-4 \mathrm{mg} / \mathrm{L}$. We fed each oyster daily with $1 \mathrm{ml}$ of a 2:500 ml

143 dilution of Shellfish Diet 1800 in deionized water (Reed Mariculture, 2 billion cells ml-1).

145 General Experimental Design Elements

146 Temperature Treatments

147 To determine if host survival and immune response, and parasite infection intensity are affected

148 by increasing air temperature, we manipulated air temperatures to eight values ranging from 27-

$14953^{\circ} \mathrm{C}$ at $3-4^{\circ} \mathrm{C}$ intervals. This range bracketed both average ambient water temperature $\left(29^{\circ} \mathrm{C}\right)$

150 and average maximum air temperature $\left(33^{\circ} \mathrm{C}\right.$, with occasional spikes above $40^{\circ} \mathrm{C}$; see

151 Supplemental Data) in Georgia during July, as well as higher air temperatures that oysters could

152 experience based on climate change scenarios (IPCC, 2014b). Previous observations indicate that

153 intertidal oysters in the Gulf of Mexico can withstand temperatures from $44-49.5^{\circ} \mathrm{C}$ for $3 \mathrm{~h}$

154 (Ingle et al., 1971). To ensure that we exceeded this thermal threshold, we also included

155 temperatures above this range, up to $53^{\circ} \mathrm{C}$. A continuously submerged subtidal treatment was

156 held at a constant water temperature of $27^{\circ} \mathrm{C}$ and acted as a procedural control. This treatment

157 was used for informal comparison purposes only and was not included in the formal analyses. 
159 We constructed experimental chambers ( 1 per temperature treatment) using 114 liter plastic bins

160 (Sterilite) wrapped on the exterior with fiberglass insulation to better maintain and stabilize

161 target air temperatures. We transferred oysters from their water-filled individual holding

162 containers to dry air temperature chambers for $4.5 \mathrm{~h}$ per day to simulate intertidal exposure, $6 \mathrm{~d}$

$163 \mathrm{wk}^{-1}$. The $4.5 \mathrm{~h}$ duration was within the range of intertidal conditions experienced in

164 Southeastern US estuaries (Byers et al., 2015). Temperature chamber bottoms were lined with

165 sand to create more natural heat absorption conditions. We suspended a clamp lamp with an

166 infrared heat bulb ranging from 75-150 watts from a hole in the center of the chamber lid to heat

167 the chambers to target temperatures. In the bottom corner of each heat chamber we put a

168 temperature sensor (Dallas OneWire DS18B20 Maxim) which was wired to an Arduino Micro

169 micro-controller attached to a breadboard. We controlled the power supply of chamber lamps

170 using 8A solid state relays which were also wired to the Arduino through the breadboard (Fig. 1).

171 Code was developed to keep the chambers within $\pm 0.5^{\circ} \mathrm{C}$ of the target temperature by turning

172 lamps on and off via the relays in response to the temperatures reported by the sensors.

\section{Host Survival Experiment}

175 To develop survival curves for the 25 oysters exposed to each air temperature treatment, we

176 recorded oyster mortality daily prior to starting air temperature exposure and upon return of

177 oysters to their individual containers. Dead oysters were easy to identify from having loose shells

178 or gaping, even when out of water. We collected tissue for P. marinus assessment from oysters

179 as soon as mortality was observed. As the parasite does not die when the host dies, we were

180 confident that fresh dead oysters would provide reliable intensity assessment. The experiment

181 ran for 3 weeks and we sampled all remaining live oysters for $P$. marinus infection at the 
182 conclusion of the experiment. Thus, we knew how long each oyster survived and its infection

183 intensity upon death or at the end of the three week experiment.

184

185 We assessed P. marinus infection status and intensity using the Ray's Fluid Thioglycollate

186 Medium (RFTM) method that detects live $P$. marinus spores in oyster tissue. Because we did not

187 expect infection status to change during the experiment due to the isolation of individual oysters,

188 we focused on the effects of air temperature on infection intensity. The RFTM methodology

189 provides an interpretable, quantitative assessment of intensity that can easily be compared with

190 previous studies. A detailed explanation for the RFTM method can be found in Malek \& Byers

191 (2017). It is modified in the current study only by the collection of gill and mantle tissue in

192 addition to rectal tissue for assessment because this increases the probability of detecting low

193 intensity infections. Briefly, tissue was incubated in RFTM for 6 days, stained with Lugol's

194 Iodine, and viewed under a dissecting microscope to score the abundance (intensity) of live $P$.

195 marinus hypnospores, which enlarge and become visible microscopically during incubation. We

196 found during the experiment that this methodology was likely limited in detecting infections at

197 high temperatures $\left(\geq 43^{\circ} \mathrm{C}\right)$ as we observed lower infection prevalence in high $\left(\geq 43^{\circ} \mathrm{C}\right)$ compared

198 to the low $\left(\leq 39^{\circ} \mathrm{C}\right)$ temperature treatments, which were more comparable to our initial baseline

199 of $60 \%$. Because the RFTM method is designed for the detection of live parasites, if parasite

200 mortality or dormancy occurred at higher temperatures, we would not be able to detect the

201 parasite within the host, thus potentially accounting for the lower prevalence that was observed.

202 Thus, for our analyses that included P. marinus intensity (see below), we excluded the

203 uppermost temperature treatments, and focused only on the range from $27-39^{\circ} \mathrm{C}$. 
205 To determine how oyster survival responds to increasing temperature and if survival was

206 affected by the interaction of temperature and the intensity of $P$. marinus infection, we used the

207 'Survival' package in R (Therneau, 2015), which utilizes Kaplan-Meier estimation to evaluate

208 survival and generate survival curves. We first analyzed survival by air temperature using the

209 full temperature range, $27-53^{\circ} \mathrm{C}$, and next analyzed survival as a function of temperature (27-

$21039^{\circ} \mathrm{C}$ ) and P. marinus infection intensity (RFTM Mackin score for $27-39^{\circ} \mathrm{C}$ ), and their

211 interaction. As aforementioned, we used a truncated temperature range for the latter analysis to

212 account for reliability issues of RFTM at high temperatures.

213

214 In addition to testing for effects of $P$. marinus infection intensity on oyster survival, we also

215 wanted to know if the parasite itself was affected by increasing air temperature. We ran a

216 separate analysis of infection intensity as a function of air temperature using a 1-way analysis of

217 variance (ANOVA), using RFTM data for the $27-39^{\circ} \mathrm{C}$ treatments. If air temperature was a

218 significant predictor of P. marinus infection intensity, we conducted post-hoc Tukey’s HSD

219 pairwise comparisons to identify differences between air temperature treatments.

220

221 Host Immune Response Experiment

222 We ran a second experiment with a new collection of individual oysters and the same

223 experimental setup described above to test for effects of increasing air temperature on $C$.

224 virginica immune response. Because immune response and survival may be linked, and for

225 comparability with survival data, we chose to again use a similarly broad and high range of air

226 temperatures. However, to achieve the best resolution and boost sample sizes, we eliminated the

22731 and $53^{\circ} \mathrm{C}$ treatments used in the previous experiment. We used 25 individuals per treatment 
228 except for higher air temperatures $\left(43-50^{\circ} \mathrm{C}\right)$ which had 35 individuals per treatment to try to

229 increase the number of days that live oysters could be sampled from those treatments (because

230 we knew the mortality rate would be high). Four times over the course of two weeks (at 2, 4, 7 ,

231 and $14 \mathrm{~d}$ ), we randomly selected six live individuals from each air temperature treatment for host

232 immune response assessment. Several high air temperature treatments experienced complete

233 oyster mortality within several days $\left(43-50^{\circ} \mathrm{C}\right)$, so only the $27-39^{\circ} \mathrm{C}$ treatments could be sampled

234 at all four time points. The exact start time of air exposure was slightly staggered on sampling

235 days so that individuals could be sampled immediately after removal from air temperature

236 chambers.

237

238 We used phagocytic activity, the primary means of protection against foreign cells, as a measure

239 of host immune response. Phagocytic activity was assessed by using fluorescent latex beads as a

240 proxy for foreign cells. We measured phagocytic consumption of beads by granulocytes (the

241 largest and most phagocytically active oyster hemocytes) in oyster hemolymph with flow

242 cytometry following the methods of Goedken \& DeGuise (2004) and instruction of M. Levin

243 (University of Connecticut, personal communication). From this assessment, we were able to

244 calculate the proportion of highly active granulocytes (those that consumed $\geq 3$ beads; hereafter,

245 'highly active cells') and the mean number of beads consumed by all granulocytes (hereafter,

246 'mean beads consumed') in each air temperature treatment. See Malek \& Byers (2016) for

247 detailed flow cytometry methods.

248

249 Because granulocytes are the first line of defense for the oyster immune response, we also tested

250 for effects of $P$. marinus infection status on phagocytic activity to better understand the 
251 relationship between the above-measured host immune response and parasite infection for each

252 oyster. Because of previously discussed issues with $P$. marinus detection at high temperatures

253 using the RFTM method, and also because we were interested in looking at the effects of the

254 presence of the parasite on hemocyte activity (Anderson et al. 1995), it was necessary to use a

255 more sensitive assay (qPCR) to detect infections (Gauthier, Miller \& Wilbur, 2006; N Stokes

256 personal communication). This methodology enabled us to detect any form of parasite DNA

257 (live, dead, or degraded) and we could evaluate P. marinus infection status across all

258 temperatures. Detailed methods for qPCR assessment, adapted from Gauthier, Miller \& Wilbur

259 (2006) and N Stokes (personal communication), can be found in Malek \& Byers (2016).

260

261 To determine if increasing temperature affected the behavior of the highly active cells and the

262 mean beads consumed within the host, and whether these traits were affected by P. marinus

263 infection, we used a series of ANOVAs, one for each sampling day $(2,4,7,14)$, that included air

264 temperature and P. marinus infection status as fixed effects. If air temperature was a significant

265 predictor of phagocytic activity, we conducted post-hoc Tukey's HSD pairwise comparisons to

266 identify differences between air temperature treatments. Each measure of phagocytic activity (the

267 proportion of highly active cells and mean beads consumed) was analyzed with separate

268 ANOVAs. We arcsine square root transformed the proportion of highly active cells (consuming

$269 \geq 3$ beads) to meet the assumptions of normality. As with the Host Survival Experiment, the $27^{\circ} \mathrm{C}$

270 subtidal treatment was not included in formal statistical analyses. All analyses were run in R

271 version 3.2.0 (R Core Team 2015).

272

273 Results 
274 Host Survival Experiment

275 There was no interactive effect of air temperature $\left(27-39^{\circ} \mathrm{C}\right)$ and $P$. marinus infection intensity

276 as measured by the RFTM method on $C$. virginica survival, but there was a significant effect of

277 air temperature (Fig. 2, Table 1). We observed a clear delineation in response to air temperature

278 between 39 and $43^{\circ} \mathrm{C}$. Air temperature treatments $\leq 39^{\circ} \mathrm{C}$ maintained at least $50 \%$ oyster survival

279 over 21 days and treatments $\geq 43^{\circ} \mathrm{C}$ reached $0 \%$ oyster survival within several days (Fig. 2).

280 There was no effect of $P$. marinus intensity on survival (Table 1a). Because we also observed

281 complete host mortality within several days at temperatures above $39^{\circ} \mathrm{C}$ (Fig. 2), the truncated

282 temperature range over which $P$. marinus infection intensity was evaluated provided more

283 ecologically relevant insights on the relationship between host and parasite.

284

285 Analysis of variance indicated that air temperature also had a significant effect on infection

286 intensity (Fig. 3, Table 2). Tukey's HSD pairwise comparisons indicated that oysters exposed to

$28735^{\circ} \mathrm{C}$ had significantly higher infection intensity than oysters exposed to other temperatures, with 288 the exception of $31^{\circ} \mathrm{C}$ (Fig. 3).

289

290

\section{Host Immune Response Experiment}

291 There was a significant effect of air temperature on both measures of phagocytic activity, but

292 only on sampling day 2, which was the one day that had equal sample sizes for all temperature

293 treatments (highly active cells $\mathrm{df}=5, \mathrm{~F}=3.084, \mathrm{p}=0.022$; mean beads consumed $\mathrm{df}=5, \mathrm{~F}=4.103$,

$294 \mathrm{p}=0.006$ ) (Fig. 4). Air temperature did not affect phagocytic activity on the other sampling days

295 ( $p>0.05)$. Tukey's HSD comparisons on day 2 indicated that the there was a significantly lower

296 proportion of highly active cells at $47(\mathrm{p}=0.046)$ and $50^{\circ} \mathrm{C}(\mathrm{p}=0.029)$ compared to $39^{\circ} \mathrm{C}$. 
297 Significantly fewer beads were consumed at $50^{\circ} \mathrm{C}$ compared to $39(\mathrm{p}=0.002)$ and $43^{\circ} \mathrm{C}$

298 ( $\mathrm{p}=0.050)$. There was no effect of $P$. marinus infection status on either measure of activity

299 ( $\mathrm{p}>0.05$ for all analyses).

300

301 Discussion

302 Climate change is predicted to affect environmental factors that shape host-parasite interactions.

303 We found that increasing air temperature can affect the traits of the oyster C. virginica and

304 infection intensity patterns of its parasite, $P$. marinus. The temperatures at which we observed

305 changes in host traits (survival) and parasite infection patterns (intensity) are within the range of

306 air temperatures projected to occur in the Southeast US within the next one hundred years

307 (Mitchum, 2011). Specifically, our results indicated that host survival decreases as temperatures

308 move towards $35^{\circ} \mathrm{C}$, then drop quickly above $39^{\circ} \mathrm{C}$. Phagocytic activity of oyster hemocytes

309 however was largely unaffected until at least $47^{\circ} \mathrm{C}$, at which point the host experienced complete

310 mortality, suggesting that increasing temperature is unlikely to affect granulocyte activity at

311 temperatures that are physiologically favorable for the host. Infections intensity of P. marinus

312 increased with temperature, peaking at $35^{\circ} \mathrm{C}$, and then declined significantly at $39^{\circ} \mathrm{C}$. Even

313 though significantly lower compared to $35^{\circ} \mathrm{C}$, intensity at $39^{\circ} \mathrm{C}$ was comparable to the intensity

314 observed at previous temperatures $\left(31^{\circ} \mathrm{C}\right)$, suggesting that the parasite may be more tolerant of

315 increases in temperature than its host, at least within the range tested (Fig. 3). As temperatures

316 rise in the intertidal, oysters may suffer not only from temperature-related mortality in the short-

317 term (weeks), but also from higher intensity P. marinus infections over the long-term (months). 318 
319 The current maximum average intertidal air temperature in mid-coast Georgia in the summer is

$320 \sim 33^{\circ} \mathrm{C}$, therefore increasing average air temperature in this region, even by several degrees,

321 could cause an increase in $P$. marinus infection intensity. The higher intensity parasite infections

322 observed at $35^{\circ} \mathrm{C}$ may be detrimental to the oyster host as intensities greater than 2 on the

323 Mackin scale are more likely to cause harm to the host through effects such as decreased shell

324 and soft tissue growth (Ray, Mackin \& Boswell, 1953; Menzel \& Hopkins, 1955), reduced

325 reproductive development (Dittman, 1993), and weakened adductor muscles (Mackin, 1962).

326 Over time, these effects can lead to host mortality. We did not find a significant relationship

327 between host survival and parasite infection intensity (Table 1). However, the relatively short

328 duration of our experiment likely prevented us from detecting negative effects of the higher

329 intensity infections, which can take months to over a year to cause host mortality, depending on

330 ambient water temperature and salinity conditions (Mackin, 1951).

332 Interestingly, we did not see an effect of air temperature on phagocytic activity, except at very

333 high temperatures. Although oyster hemocytes have been shown to be sensitive to environmental

334 factors such as temperature, salinity, air exposure, and parasite infection (Fisher, Chintala \&

335 Moline, 1989; Anderson, Paynter \& Burreson, 1995; Hégaret, Wikfors \& Soudant, 2003;

336 Duchemin, Fournier \& Auffret, 2007; Kuchel et al., 2010), our results suggest that air

337 temperature only affected hemocyte activity at temperatures that cause rapid oyster mortality.

338 These effects of temperature were only analyzable across the full temperature range on day 2 ,

339 which was the single sampling day on which we had samples from all temperatures due to high

340 oyster mortality above $39^{\circ} \mathrm{C}$. Thus, any continuation of the pattern of decreased phagocytic

341 activity at these temperatures over time would not be ecologically significant as the oyster would 
342 die from temperature exposure before any adverse impacts of decreased phagocytic activity

343 occurred.

344

345 Hemocyte characteristics can be sensitive to parasite infections (Anderson et al. 1995) and $P$.

346 marinus in particular can use host phagocytic activity as a means to facilitate entry into host

347 hemocytes (Tasumi \& Vasta, 2007). However, our results indicated no effect of $P$. marinus

348 infection status on phagocytic activity. Similarly, Keppel et al. (2015) found that P. marinus

349 intensity scores did not correlate with hemocyte activity. The presence of the parasite alone,

350 which can affect hemocyte number (Anderson, Paynter \& Burreson, 1995), may not influence

351 the activity of hemocytes, and other immune functions (i.e., apoptosis) may be more important

352 for regulating or responding to P. marinus infection (Anderson, Paynter \& Burreson, 1992;

353 Goedken et al., 2005).

355 Conclusions

356 There is much speculation about how changes in climate will affect host-parasite interactions

357 (Harvell et al., 2009; Lafferty, 2009). Our study suggests, at least for oysters and one of their

358 most detrimental parasites, that a temperature increase of just a few degrees above the current

359 intertidal average in Georgia could affect host survival and lead to higher intensity P. marinus

360 infections. Similar to air temperature, water temperature is also predicted to increase (IPCC,

361 2014a), and may have similar effects on $P$. marinus infections as the parasite grows and

362 reproduces more quickly at warmer temperatures (Andrews, 1988; Chu \& Volety, 1997). Though

363 we looked at air temperature in isolation, global environmental change likely will result in

364 concomitant changes in water and air temperature, and other factors (e.g., water acidity, salinity, 
365 oxygen concentrations), that may have interactive effects that could further influence host and

366 parasite characteristics and interactions. Observed changes in C. virginica populations in the

367 future may more likely be temperature-related over the short-term as temperature increases but

368 be more parasite-driven as higher intensity infections, influenced by increased temperature,

369 begin to impact the host over the longer term. Recognizing that host and parasite responses to

370 increasing temperatures differ and may be variable across temporal scales will help us to more

371 effectively shape our future research initiatives for other ecologically and economically valuable

372 species, and develop a stronger understanding of the relationship between changes in climate,

373 hosts, and their parasites.

374

375 Acknowledgements

376 The authors thank the University of Georgia Marine Extension Shellfish Research Lab for

377 providing a temperature-controlled space to complete these experiments, the UGA Skidaway

378 Institute of Oceanography for field site access. We would also like to especially thank Camden

379 Lowrance for developing the code to run the air temperature chambers, as well as Daniel Harris,

380 Chris Malek, and Ashton Potter who assisted with the electrical and technical setup of the

381 Arduino system. The Byers' lab and Kristy McDowell provided significant feedback on this

382 manuscript and Morgan Walker provided substantial assistance in experimental setup and oyster 383 processing. 


\section{References}

387 Allen CD, Macalady AK, Chenchouni H, Bachelet D, McDowell N, Vennetier M, Kitzberger T, 388 Rigling A, Breshears DD, Hogg EH, Gonzalez P, Fensham R, Zhang Z, Castro J, Demidova N, 389 Lim J-H, Allard G, Running SW, Semerci A, Cobb N. 2010. A global overview of drought and 390 heat-induced tree mortality reveals emerging climate change risks for forests. Forest Ecology 391 Management 259:660-684.

392

393 Al-Zahraa HG. 2008. Effects of commutative heat stress on immunoresponses in broiler chickens 394 reared in closed system. International Journal of Poultry Science 7:964-968.

396 Anderson RS, Paynter KT, Burreson EM. 1992. Increased reactive oxygen intermediate 397 production by hemocytes withdrawn from Crassostrea virginica infected with Perkinsus 398 marinus. Biological Bulletin 183:476-481.

399

400 Anderson RS, Burreson EM, Paynter KT. 1995. Defense responses of hemocytes withdrawn 401 from Crassostrea virginica infected with Perkinsus marinus. Journal of Invertebrate Pathology $40266: 82-89$.

403

404 Andrews JD. 1988. Epizootiology of the disease caused by the oyster pathogen Perkinsus 405 marinus and its effects on the oyster industry. American Fisheries Society Special Publication 406 18: 47-63. 
408 Breitburg DL, Hondorp D, Audemard C, Carnegie RB, Burrell RB, Trice M, Clark V. 2015.

409 Landscape-level variation in disease susceptibility related to shallow-water hypoxia. PLoS ONE

$410 \quad 10: \mathrm{e} 0116223$.

411

412 Byers JE, Grabowski JH, Piehler MF, Hughes AR, Weiskel HW, Malek JC, Kimbro DL, 2015.

413 Geographic variation in intertidal oyster reef properties and the influence of tidal prism.

414 Linmology and Oceanography 60: 1051-1063.

415

416 Cheng W, Hsiao I-S, Hsu C-H, Chen J-C. 2004. Change in water temperature on the immune

417 response of Taiwan abalone Haliotis diversicolor supertexta and its susceptibility to Vibrio

418 parahaemolyticus. Fish \& Shellfish Immunology 17:235-243.

419

420 Chisholm JRS, Smith VJ. 1994. Variation of antibacterial activity in the haemocytes of the shore

421 crab, Carcinus maenas, with temperature. Journal of the Marine Biological Association of the

422 United Kingdom 74:979-982.

423

424 Chu FLE, Volety AK. 1997. Disease processes of the parasite Perkinsus marinus in eastern

425 oyster Crassostrea virginica: minimum dose for infection initiation, and interaction of

426 temperature, salinity and infective cell dose. Diseases of Aquatic Organisms 28: 61-68.

427

428 Crick HQP, Sparks TH. 1999. Climate change related to egg-laying trends. Nature 399:423-423. 429 
430 Dittman DE. 1993. The quantitative effects of Perkinsus marinus on reproduction and condition

431 in the eastern oyster, Crassostrea virginica (Abstract). Journal of Shellfish Research 12:127.

432

433 Dittmar J, Janssen H, Kuske A, Kurtz J, Scharsack JP. 2014. Heat and immunity: an

434 experimental heat wave alters immune functions in three-spined sticklebacks (Gasterosteus 435 aculeatus). Journal of Animal Ecology 83:744-757.

436

437 Duchemin MB, Fournier M, Auffret M. 2007. Seasonal variations of immune parameters in 438 diploid and triploid Pacific oysters, Crassostrea gigas (Thunberg). Aquaculture 264: 73-81.

440 Fisher WS, Chintala MM, Moline MA. 1989. Annual variation of estuarine and oceanic oyster

441 Crassostrea virginica Gmelin hemocyte capacity. Journal of Experimental Marine Biology \& 442 Ecology 127:105-120.

443

444 Ford SE, Chintala MM. 2006. Northward expansion of a marine parasite: testing the role of 445 temperature adaptation. Journal of Experimental Marine Biology \& Ecology 339:226-235. 446

447 Ford S, Smolowitz R. 2007. Infection dynamics of an oyster parasite in its newly expanded 448 range. Marine Biology 151:119-133.

450 Ganser AM, Newton TJ, Haro RJ. 2015. Effects of elevated water temperature on physiological 451 responses in adult freshwater mussels. Freshwater Biology 60:1705-1716. 
453 Gauthier JD, Miller CR, Wilbur AE. 2006. Taqman ${ }^{\circledR}$ mgb real-time pcr approach to

454 quantification of Perkinsus marinus and Perkinsus spp. in oysters. Journal of Shellfish Research 455 25:619-624.

456

457 Gehman AM, Hall RJ, Byers JE. 2018. Host and parasite thermal ecology jointly determine the 458 effect of climate warming on epidemic dynamics. Proceedings of the National Academy of 459 Science 115(4): 744-749. doi: 10.1073/pnas.1705067115.

460

461 Gillooly JF, Brown JH, West GB, Savage VM, Charnov EL. 2001. Effects of size and 462 temperature on metabolic rate. Science 293:2248-2251.

463

464 Goedken M, De Guise S. 2004. Flow cytometry as a tool to quantify oyster defense mechanisms. 465 Fish \& Shellfish Immunology 16:539-552.

466

467 Goedken M, Morsey B, Sunila I, De Guise S. 2005. Immunomodulation of Crassostrea gigas 468 and Crassostrea virginica cellular defense mechanisms by Perkinsus marinus. Journal of 469 Shellfish Research 24:487-496.

470

471 Harvell CD, Mitchell CE, Ward JR, Altizer S, Dobson AP, Ostfeld RS, Samuel MD. 2002.

472 Climate warming and disease risks for terrestrial and marine biota. Science 296:2158-2162.

473

474 Harvell D, Aronson R, Baron N, Connell J, Dobson A, Ellner S, Gerber L, Kim K, Kuris A, 475 McCallum H, Lafferty K, McKay B, Porter J, Pascual M, Smith G, Sutherland K, Ward J. 2004. 
476 The rising tide of ocean diseases: unsolved problems and research priorities. Frontiers in 477 Ecology \& the Environment 2:375-382.

478

479 Harvell D, Altizer S, Cattadori IM, Harrington L, Weil E. 2009. Climate change and wildlife 480 diseases: When does the host matter the most? Ecology 90:912-920.

481

482 Hégaret H, Wikfors GH, Soudant P. 2003. Flow cytometric analysis of haemocytes from eastern 483 oysters, Crassostrea virginica, subjected to a sudden temperature elevation: II. Haemocyte 484 functions: aggregation, viability, phagocytosis, and respiratory burst. Journal of Experimental 485 Marine Biology \& Ecology 293:249-265.

486

487 Ingle RM, Joyce AE, Quick JA, Morey, SW. 1971. Basic considerations in the valuation of 488 thermal effluents in Florida. A preliminary investigation: The effect of elevated temperature on 489 the American oyster Crassostrea virginica (Gmelin). Florida Department of Natural Resources 490 Professional Paper Series 15:vii-viii.

491

492 IPCC, 2014a: Climate Change 2014: Impacts, Adaptation, and Vulnerability. Part A: Global and 493 Sectoral Aspects. Contribution of Working Group II to the Fifth Assessment Report of the 494 Intergovernmental Panel on Climate Change. (eds. Field CB, Barros VR, Dokken DJ, Mach KJ, 495 Mastrandrea MD, Bilir TE, Chatterjee M, Ebi KL, Estrada YO, Genova RC, Girma B, Kissel ES, 496 Levy AN, MacCracken S, Mastrandrea PR, White LL). 1132 pp. Cambridge University Press, 497 Cambridge, United Kingdom and New York, NY, USA. 498 
499 IPCC, 2014b: Climate Change 2014: Impacts, Adaptation, and Vulnerability. Part B: Regional

500 Aspects. Contribution of Working Group II to the Fifth Assessment Report of the

501 Intergovernmental Panel on Climate Change. (eds. Field CB, Barros VR, Dokken DJ, Mach KJ,

502 Mastrandrea MD, Bilir TE, Chatterjee M, Ebi KL, Estrada YO, Genova RC, Girma B, Kissel ES,

503 Levy AN, MacCracken S, Mastrandrea PR, White LL). 688 pp. Cambridge University Press,

504 Cambridge, United Kingdom and New York, NY, USA.

505

506 Janzen FJ. 1994. Climate change and temperature-dependent sex determination in reptiles.

507 Proceedings of the National Academy of Science 91, 7487-7490.

508

509 Keppel AG. 2014. The effects of co-varying diel-cycling hypoxia and $\mathrm{pH}$ on disease

510 susceptibility, growth, and feeding in Crassostrea virginica. MS Thesis submitted to the

511 University of Maryland, College Park, MD, USA.

512

513 Keppel AG, Breitburg DL, Wikfors GH, Burrell RB, Clark VM. 2015. Effects of co-varying diel

514 cycling hypoxia and $\mathrm{pH}$ on disease susceptibility in the eastern oyster, Crassostrea virginica.

515 Marine Ecology Progress Series 538: 169-183.

516

517 Kuchel RP, Raftos DA, Birch D, Vella N. 2010. Haemocyte morphology and function in the 518 Akoya pearl oyster, Pinctada imbricata. Journal of Invertebrate Pathology 105:36-48.

519

520 Lafferty KD. 2009. The ecology of climate change and infectious diseases. Ecology 90: 888521900. 
523 Lafferty KD, Porter JW, Ford SE. 2004. Are diseases increasing in the ocean? Annual Review of

524 Ecology \& Evolution S 35:31-54

525

526 Lesser MP, Farrell JH. 2004. Exposure to solar radiation increases damage to both host tissues

527 and algal symbionts of corals during thermal stress. Coral Reefs 23:367-377.

528

529 Mackin JG. 1951. Incidence of infection of oysters by Dermocystidium marinum in the Barataria

530 Bay area of Louisiana. Proceedings of the National Shellfish Association 23-35.

531

532 Mackin JG. 1962. Oyster diseases caused by Dermocystidium marinum and other

533 microorganisms in Louisiana. Publication of the Institute of Marine Science at the University of

534 Texas 7:132-229.

535

536 Mackin JG, Owen HM, Collier A. 1950. Preliminary Note on the occurrence of a new protistan

537 parasite, Dermocystidium marinum n. sp. in Crassostrea virginica (Gmelin). Science 111:328538329.

539

540 Malek, JC, Byers, JE. 2016. Predator effects on host-parasite interactions in the eastern oyster,

541 Crassostrea virginica. Marine Ecology Progress Series 556: 131-141.

542 
543 Malek JC, Byers JE. 2017. The effects of tidal elevation on parasite heterogeneity and co-

544 infection in the eastern oyster, Crassostrea virginica. Journal of Experimental Marine Biology \& 545 Ecology 494: 32-37.

546

547 Menzel RW, Hopkins SH. 1955. The growth of oysters parasitized by the fungus

548 Dermocystidium marinum and by the Trematode Bucephalus cuculus. Journal of Parasitology $549 \quad 41: 333-342$.

550

551 Moore JD, Robbins TT, Friedman CS. 2000. Withering syndrome in farmed red abalone Haliotis

552 rufescens: thermal induction and association with a gastrointestinal rickettsiales-like prokaryote.

553 Journal of Aquatic Animal Health 12:26-34.

554

555 Mouritsen KN, Jensen KT. 1997. Parasite transmission between soft-bottom invertebrates:

556 temperature mediated infection rates and mortality in Corophium volutator. Marine Ecology

557 Progress Series 151:123-134.

558

559 Mydlarz LD, Holthouse SF, Peters EC, Harvell CD. 2008. Cellular Responses in Sea Fan Corals:

560 Granular Amoebocytes React to Pathogen and Climate Stressors. PLoS ONE 3:1-9.

561

562 Mydlarz LD, Couch CS, Weil E, Smith G, Harvell CD. 2009. Immune defenses of healthy,

563 bleached and diseased Montastraea faveolata during a natural bleaching event. Diseases of 564 Aquatic Organisms 87:67-78. 
566 Poulin R. 2006. Global warming and temperature-mediated increases in cercarial emergence in

567 trematode parasites. Parasitology 132:143-151.

568

569 Pounds AJ, Bustamante MR, Coloma LA, Consuegra JA, Fogden MPL, Foster PN, La Marca E.

570 2006. Widespread amphibian extinctions from epidemic disease driven by global warming.

571 Nature 439, 161-67.

572

573 R Core Team. 2015. R: A language and environment for statistical computing. R Foundation for

574 Statistical Computing, Vienna, Austria. ISBN 3-900051-07-0, URL http://www.R-project.org/

575

576

Raffel TR, Rohr JR, Kiesecker JM, Hudson PJ. 2006. Negative effects of changing temperature on amphibian immunity under field conditions. Functional Ecology 20:819-828.

578

579

Ray S, Mackin JG, Boswell JL. 1953. Quantitative measurement of the effect on oysters of disease caused by Dermocystidium Marinum. Bulletin of Marine Science 3:6-33.

581

582 Soniat TM, Klinck JM, Powell EN, Hofmann EE. 2006. Understanding the success and failure of 583 oyster populations: climatic cycles and Perkinsus marinus. Journal of Shellfish Research 25:83584 93.

585

586 Soniat TM, Hofmann EE, Klinck JM, Powell EN. 2008. Differential modulation of eastern oyster

587 (Crassostrea virginica) disease parasites by the El-Niño-Southern Oscillation and the North

588 Atlantic Oscillation. International Journal of Earth Science 98:99-114. 
590 Tasumi S, Vasta G. 2007. A Galectin of Unique Domain Organization from Hemocytes of the

591 Eastern Oyster (Crassostrea virginica) Is a Receptor for the Protistan Parasite Perkinsus

592 marinus. Journal of Immunology 179: 3086-3098.

593

594 Therneau T. 2015. A Package for Survival Analysis in S. version 2.38, http://CRAN.R595 project.org/package= $=$ survival

596

597 Walther G-R, Post E, Convey P, Menzel A, Parmesan C, Beebee TJC, Fromentin J-M, Hoegh598 Guldberg O, Bairlein F. 2002. Ecological responses to recent climate change. Nature 41:389599395.

600

601 Wang F, Yang H, Gao F, Liu G. 2008. Effects of acute temperature or salinity stress on the 602 immune response in sea cucumber, Apostichopus japonicus. Comparative Biochemisty \& 603 Physiology A 151:491-498.

604

605 Wang X, Wang L, Zhang H, Ji Q, Song L, Qiu L, Zhou Z, Wang M, Wang L. 2012 Immune 606 response and energy metabolism of Chlamys farreri under Vibrio anguillarum challenge and 607 high temperature exposure. Fish \& Shellfish Immunology 33: 1016-1026. 608

609 Ward JR, Kim K, Harvell CD. 2007. Temperature affects coral disease resistance and pathogen 610 growth. Marine Ecology Progress Series 329:115-121. 


\section{Table $\mathbf{1}$ (on next page)}

Results of 1-way ANOVA testing for the effect of air temperature $\left(27-39^{\circ} \mathrm{C}\right)$ on $P$. marinus infection intensity in the Host Survival Experiment.

Infection intensity is based on RFTM assessment. 
1 Table 1.

a. Survival by air temperature treatment $\left(27-53^{\circ} \mathrm{C}\right)$

\begin{tabular}{|c|c|c|c|c|c|}
\hline Source & Coef & $\operatorname{Exp}(\operatorname{coef})$ & SE(coef) & $\mathbf{Z}$ & $\mathbf{p}(\mathrm{z})$ \\
\hline Air Temperature & 0.216 & 1.242 & 0.019 & 11.6 & $<0.001$ \\
\hline \multicolumn{6}{|c|}{ b. Survival by air temperature treatment and $\mathrm{P}$. marinus infection intensity $\left(27-39^{\circ} \mathrm{C}\right)$} \\
\hline Source & Coef & $\operatorname{Exp}(\operatorname{coef})$ & SE(coef) & $\mathbf{Z}$ & $\mathbf{p}(\mathbf{z})$ \\
\hline Air Temperature & 0.112 & 1.118 & 0.050 & 2.217 & 0.027 \\
\hline Infection Intensity & 0.552 & 1.737 & 1.342 & 0.412 & 0.681 \\
\hline Temperature*Intensity & -0.013 & 0.987 & 0.039 & -0.346 & 0.729 \\
\hline
\end{tabular}

2

3 


\section{Table 2 (on next page)}

Results of Kaplan Meier analysis of $C$. virginica survival in the Host Survival Experiment, based on a. air temperature and $b$. air temperature and $P$. marinus infection intensity.

Infection intensity is based on RFTM assessment. 
1 Table 2.

P. marinus infection intensity by air temperature $\left(27-39^{\circ} \mathrm{C}\right)$ and survival status

\begin{tabular}{|llllll|}
\hline Source & Df & Sum of Squares & Mean Square & F Value & P(F) \\
\hline Air Temperature & 3 & 10.615 & 3.538 & 4.522 & 0.009 \\
\hline
\end{tabular}

2 


\section{Figure 1}

Experimental chamber setup.

A 114 liter plastic bin was lined with sand and had a heat lamp suspended through a hole in the lid (red circle). A temperature sensor was placed in the chamber just above the surface of the sand (small black rectangle). Both the heat lamp and the temperature sensor were wired to an Arduino Micro microcontroller attached to a breadboard (white rectangle to right of the chamber). The heat lamp was turned on and off through the Arduino based on the temperatures relayed back by the sensor. This system kept the chamber within $\pm 0.5^{\circ} \mathrm{C}$ of the target temperature.

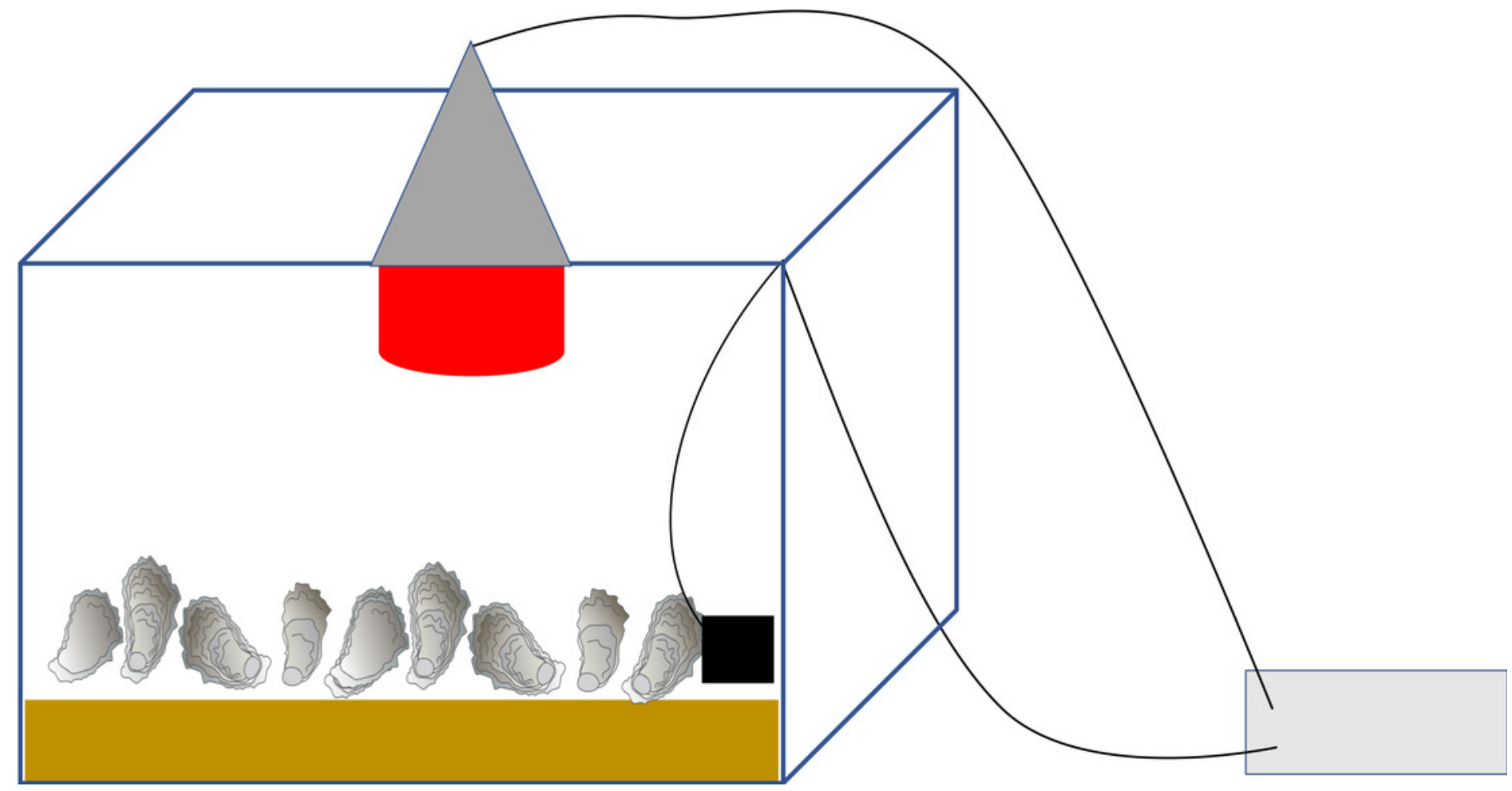


Figure 2

Total survival of all experimental oysters by air temperature, regardless of infection status.

$n \approx 25$ for each air temperature curve.

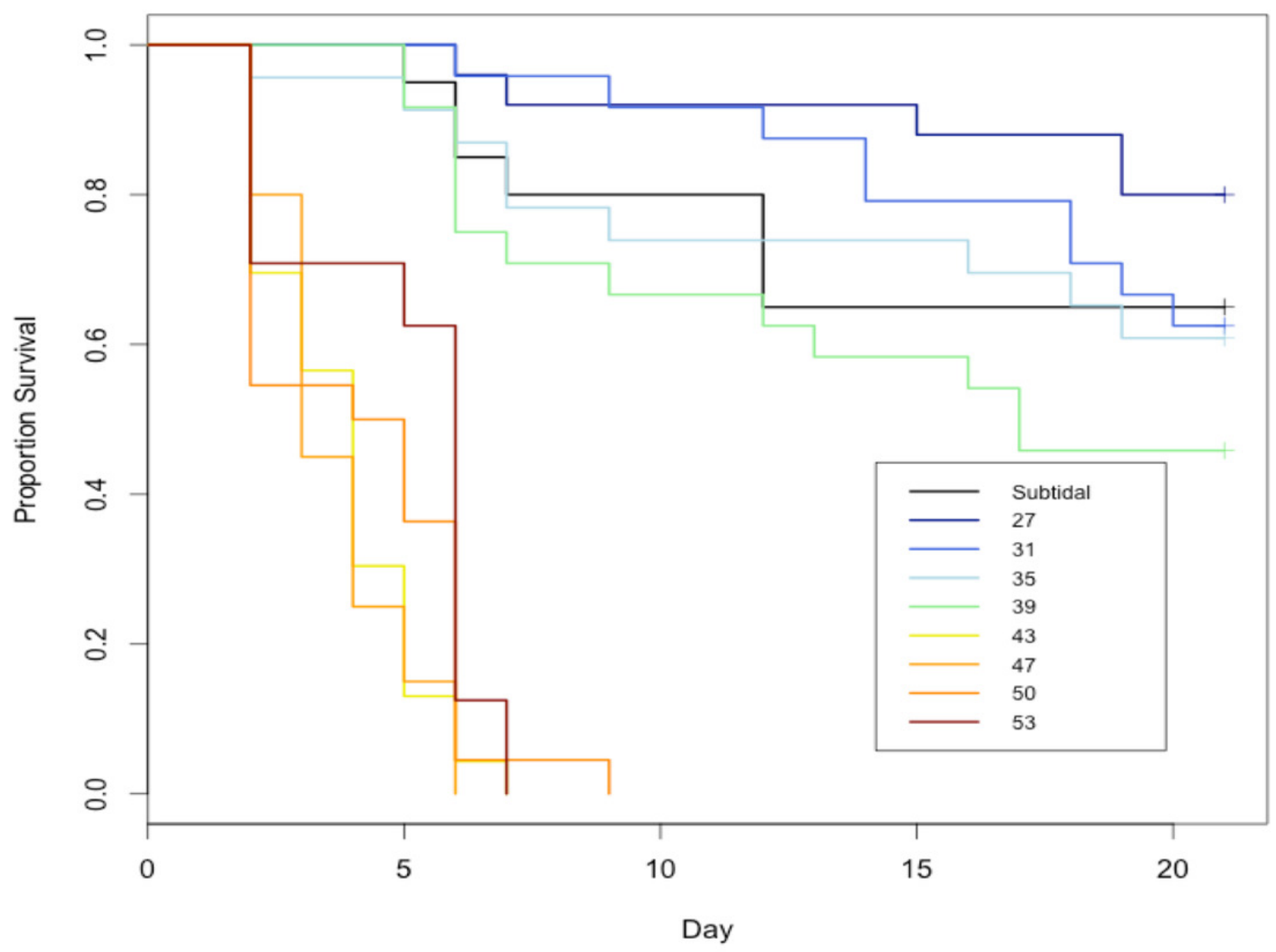




\section{Figure 3}

Mean $P$. marinus infection intensity (based on RFTM assessment) by air temperature treatment (subtidal- $39^{\circ} \mathrm{C}$ ) in the Host Survival Experiment.

Mean intensity was calculated using only infected oysters (both live and dead) and the numbers inside the bars indicate the number of infected oysters used to calculate mean intensity for each treatment. Standard error bars were calculated across individual oysters within each treatment. Capital letters indicate results of post hoc Tukey's HSD analysis; different letters indicate statistically significant differences between treatments and similar letters indicate no statistical difference between treatments.

*Note: Auto Gamma Correction was used for the image. This only affects the reviewing manuscript. See original source image if needed for review.

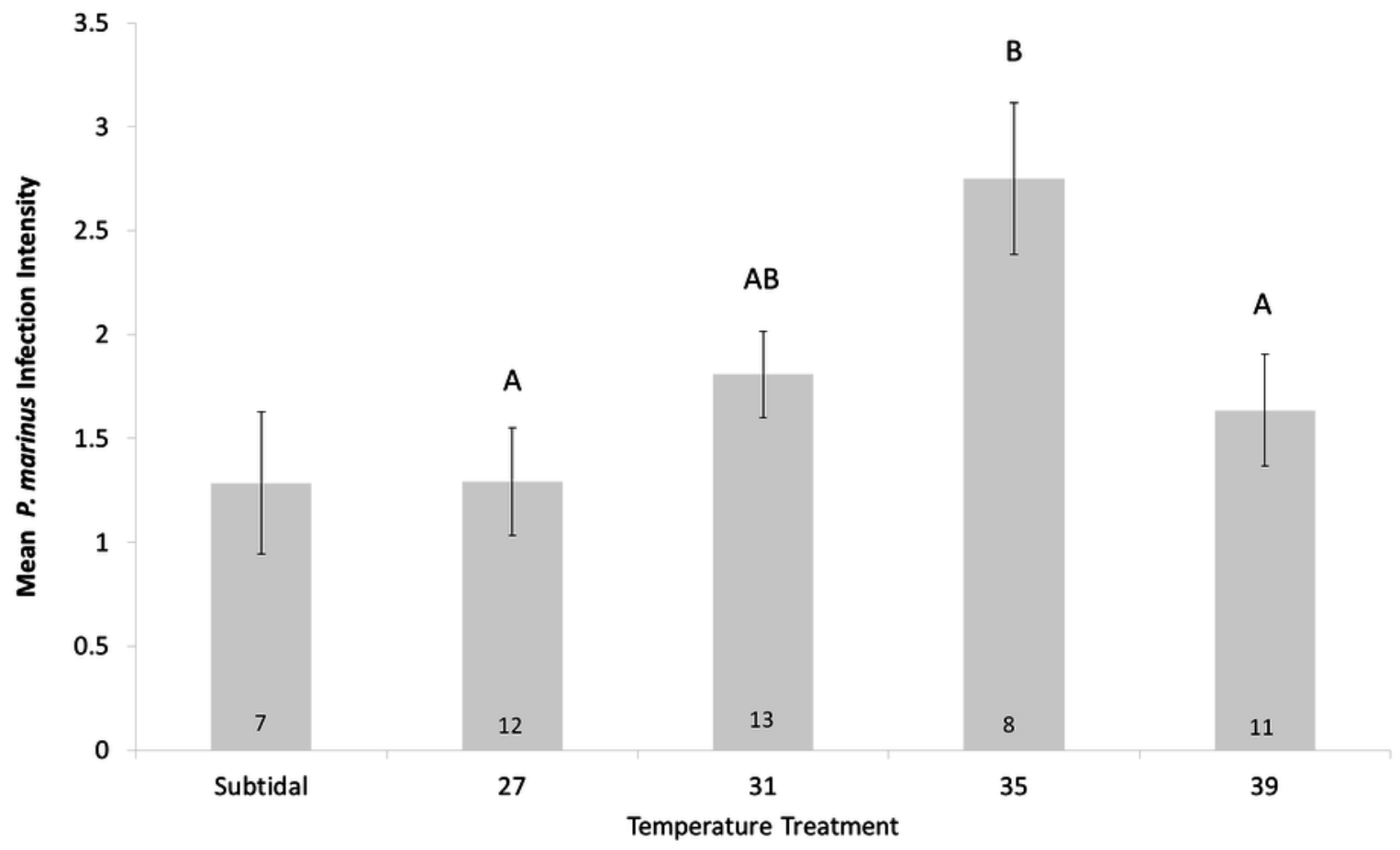




\section{Figure 4}

Phagocytic activity of granular oyster hemocytes (granulocytes) in the Host Immune Response Experiment on sampling day 2

a. the mean proportion of highly active cells (indexed by the consumption of $\geq 3$ fluorescent beads; left column) and $\mathbf{b}$. the mean number of beads consumed (sum of beads consumed by all cells; right column) in response to air temperature. Error bars represent standard error calculated across individual oysters within each air temperature treatment $(n=6$ for each treatment). Capital letters indicate results of post hoc Tukey's HSD analysis; different letters indicate statistically significant differences between treatments and similar letters indicate no statistical difference between treatments.

*Note: Auto Gamma Correction was used for the image. This only affects the reviewing manuscript. See original source image if needed for review.
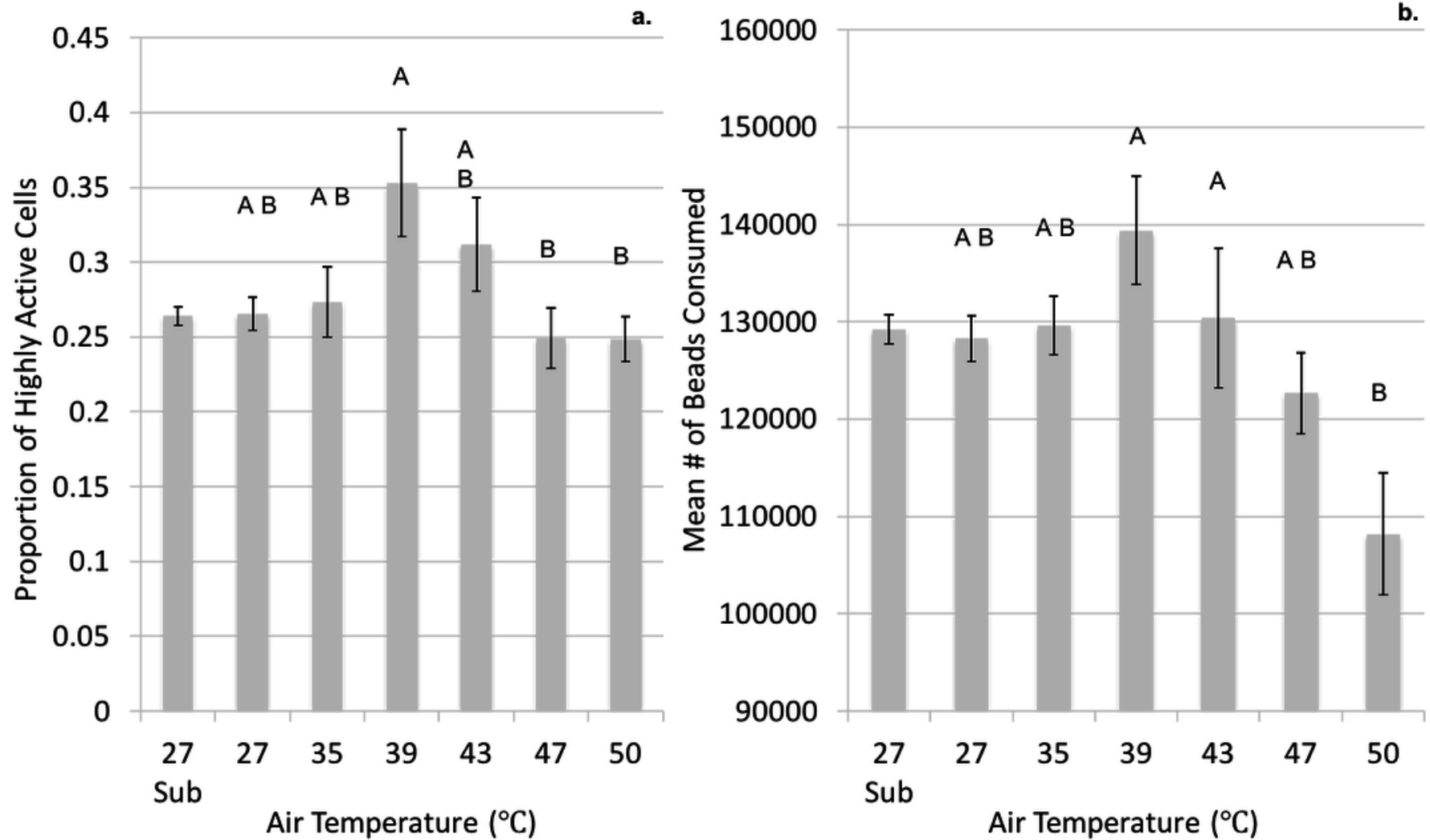